\section{Awareness level on the role of forensic DNA database in criminal investigation in Nigeria: A case study of Benin city}

\author{
Nwawuba Stanley Udogadi* and Akpata Chinyere Blessing \\ Nkiruka
}

Centre for Forensic Programmes and DNA Studies, University of Benin, P.M.B. 1154, Benin City, Nigeria

\section{Summary}

Pieces of evidence have continued to emerge, demonstrating the extensive efficiency and effectiveness of the DNA database in assisting criminal investigations around the world. Therefore, the present study aimed to determine the awareness level on the prominent role of Forensic DNA Database on Crime Investigation in Nigeria: a case study of Benin City. In conducting this research, a total of 458 questionnaires were distributed around Benin City between the periods of $12^{\text {th }}$ January 2020 to $21^{\text {st }}$ March 2020, with a particular focus on security agents and students. The questionnaire comprised of three main categories: Socio-demographic characteristics, Information about the National Forensic DNA Database, and Information about DNA evidence, and Nigeria Criminal Justice system. For the analysis of data collected; the statistical tool used was also Statistical Package for Social Sciences, version 22 for windows. Responses were compared using chi-square and presented as counts and percentages. In determining the level of awareness, the following responses were obtained. Of the total population: $53.28 \%$ had no idea about forensics, $19.21 \%$ were uncertain and $27.54 \%$ knew about forensics. The same trend was observed with Forensic DNA profiling, 42.14\% did not know, 22.27\% were uncertain and $35.59 \%$ demonstrated good knowledge of Forensic DNA profiling. On the knowledge about the National Forensic DNA Database, $48.47 \%$ had no knowledge, $22.27 \%$ were uncertain and $29.26 \%$ were knowledgeable about it. The result of the present study revealed that the awareness level of the forensic DNA Database was found to be inadequate.

\author{
More Information \\ *Address for Correspondence: \\ Nwawuba Stanley Udogadi, Centre for Forensic \\ Programmes and DNA Studies, University of \\ Benin, P.M.B. 1154, Benin City, Nigeria, \\ Tel: +234-8065699068; +234-8035908951; \\ Email: nwawubastanley@gmail.com; \\ nkiruka.akpata@uniben.edu
}

Submitted: November 13, 2020

Approved: December 14, 2020

Published: December 15, 2020

How to cite this article: Nwawuba SU, Akpata CBN. Awareness level on the role of forensic DNA database in criminal investigation in Nigeria: A case study of Benin city. J Forensic Sci Res. 2020; 4: 007-014.

DOI: 10.29328/journal.jfsr.1001019

ORCiD: orcid.org/0000-0003-0848-3791

Copyright: (c) 2020 Nwawuba SU, et al. This is an open access article distributed under the Creative Commons Attribution License, which permits unrestricted use, distribution, and reproduction in any medium, provided the original work is properly cited.

Keywords: DNA database in Nigeria; Forensic science; Forensic DNA database; DNA profiling

Check for updates

OPEN ACCESS

\section{Introduction}

In recent times, the admissibility of DNA evidence is widely used in numerous courts around the world. Its underpinning science is consistent, reproducible, accurate, and founded on authenticated technology and techniques for the generation, comparison, and interpretation of a DNA profile [1]. Forensic DNA databases have proved to be an indispensable tool in preventing miscarriages of justice and deterring offenders from further criminal activity [2-4]. To achieve a momentous decrease in the rate at which crimes are committed, and credible detection rates, a switch from the traditional 'reactive' model of crime investigation to a modern model of investigation is vital [5]. The use of DNA to trace crime suspects has been a prominent improvement in policing, and when DNA databases are efficiently put to use, it overwhelmingly aids the conviction of culprits and exoneration of the innocent [6].

In the same light, forensic DNA databases constitute a central investigative resource in modern-day criminal justice systems. According to Jakovski, et al. (2017), back-of-theenvelope estimated that the marginal cost of averting each crime suggests that DNA databases are considerably more economical relative to other common law enforcement tools [6]. Accordingly, in 1995, comprehensive legislation was enacted in the UK empowering forensic scientists to create the first national DNA database that would hold both personal DNA profiles, as well as the results obtained from crime scenes [7]. Other countries followed suit, but in some, the legislation greatly constrained the amount and type of data that can be retained in the database and as a result, the efficacy of 
the databases was lacking [7]. Presently, it is reported that around 69 countries hold functional national forensic DNA databases, and at least 34 additional countries are positioned for expansion and establishment $[7,8]$.

An extensive literature search revealed a paucity of the research report on forensic DNA databases in Africa. However, commendable progress has been recorded, and from the limited research reports, it was demonstrated that South Africa, Egypt, and Botswana holds a DNA database respectively [9-11]. In South Africa, a catalyst for the establishment of forensic DNA database, and the evolution of expedition of the forensic community in South Africa, was the instance the Criminal Law (Forensic Procedures) Amendment Act (2013) was passed [11]. From that time on, the use of DNA in South Africa within the forensic framework continued to be the gold standard for crime investigation and identification purposes to the law $[11,12]$. The capacity of Egypt DNA database was reported to contain 1046 reference DNA profiles from individuals, 869 crime scene DNA profiles, 20 missing person DNA profiles plus 1815 unidentified human remains DNA profiles FDNAPI 2018, and Botswana's DNA database was reported to contain 3500 reference DNA profiles from individuals and 300 crime scene DNA profiles [9]. Additionally, a study conducted in Egypt by El-Alfy and El-Hafez (2012) revealed that fifteen STR loci are used for identification and paternity testing [13], similarly, fifteen STR loci are been used for identification and paternity in Botswana as well $[14,15]$. It is rather ill-starred that Nigeria does not currently hold a National Forensic Database, and the state of privation of forensic skills and equipment, negatively impacts the forensic investigation capacity of the police and other security outfits in Nigeria [16]. Therefore, the present study sought to investigate the awareness level on the usefulness of forensic DNA database in crime investigation among Nigerian with a particular interest in the security agents and those with law backgrounds.

\section{Materials and methods}

\section{Population and sample size}

The sample population of the present study was five hundred (500). The sample population was drawn from three categories using the stratified random sampling technique, the categories include Six (6) Police Stations, one (1) Military Barrack, one (1) High Court, and the University of Benin. This is because the selected categories form the majority of those who should know about the Forensic Database.

\section{Research instrument}

For this research work, the research instrument adopted was a formal standardized questionnaire. A total of 500 questionnaires were distributed around Benin City, Edo State, Nigeria between the periods of $12^{\text {th }}$ January 2020 to $21^{\text {st }}$ March 2020. However, only four hundred fifty-eight
(458) responded. The questionnaire comprised of three main categories:

1. Socio-demographic characteristics, including the following: Gender, Age, Occupation, Educational Background, and Area of Discipline.

2. Information about the National Forensic DNA Database, covering the following: Information about Forensic, Information about DNA, Information about Forensic DNA Profiling, Information about National Forensic DNA database, the meaning of National Forensic DNA database, information on the usefulness of National Forensic DNA database, Source of information about National Forensic DNA Database, and information to know if Nigeria holds a National Forensic DNA database.

3. Information about DNA evidence and Nigeria Criminal Justice system, covering the following: There is a relationship between Forensic Science and Law, DNA is admissible as evidence in Nigeria Criminal Justice System, Forensic DNA database is available and in use in Nigeria Criminal Justice System, and There is existing legislation that allows for the establishment of a National Forensic DNA database in Nigeria.

\section{Method of data collection}

a) Primary Source of Data

The primary data for this research work was generated through the use of questionnaires.

b) Secondary Source of Data

The source of secondary data includes; a comprehensive electronic literature search using PubMed, ScienceDirect, Google Scholar, and Google Search. The following keywords and their combinations were used: "DNA Database" "Forensic DNA profiling", "Forensic DNA database in Africa", "Prevalence of Crime in Nigeria", and "Forensic Science". All works meeting the subject matter were considered, including reviews, meta-analyses, retrospective studies, observational studies, organization recommendations, and original articles. Preference was placed on the most recent papers.

\section{Measurement of variable}

The present study tested all variables through the use of the questionnaires using Statistical Package for Social Sciences, version 22 for windows.

\section{Data analysis techniques}

In the analysis of data collected; the statistical tool used was also Statistical Package for Social Sciences, version 22 for windows. Responses were compared using chi-square and presented as counts and percentages. Based on the level of significance; Asymptotic significance (2-sided) was used, for the association between variables; Pearson's chi-square was 
used, for symmetric measurement on strength of association; Phi and Cramer's V was used and $p<0.05$ was considered statistically significant.

Like most statistics test, to use the Chi-Square test successfully, certain assumptions must be met. They are:

- No cell should have an expected value (count) less than 0 [17].

- No more than $20 \%$ of the cells have expected values (counts) less than 5 [17].

- The sample size is sufficiently large. The application of the Chi-square test to a smaller sample could lead to type II error (i.e. accepting the null hypothesis when it is false). There is no expected cut-off for the sample size; however, the minimum sample size varies from 20 to 50 [18].

- The variables under consideration must be mutually exclusive. In other, words no item shall be counted twice [18].

- Phi and Cramer's V Interpretation; > 0.25 Very strong, $>0.15$ Strong, $>0.10$ Moderate, $>0.05$ Weak $>0$ No or very weak [19].

The present study's statistical test met all the stated assumptions.

\section{Ethical consideration}

Voluntary participation: Respondents were informed of the purpose of the study. They were informed that their participation in the study was voluntary and not paid for. They were also informed that the information provided was strictly for academic research purposes, and were requested to kindly provide honest responses to ensure the credibility of the study.

Anonymity and confidentiality: The respondents were informed that their identity was confidential and as such their detail of names were not collected.

\section{Results}

\section{Social demographic information}

The present study gathered quantitative data via a well-structured questionnaire, and our results on social demographic distribution revealed that, from the population of 458 , there was a total of $59.83 \%$ population of male respondents and a total of $40.17 \%$ female respondents respectively as demonstrated in figure 1 . A wide range of ages was considered, and the result of the present study revealed that the predominant populations of the respondents were between 19-24 years of age with $29.48 \%$, followed by $25-29$ years of age with $27.5 \%$. Conversely, $\geq 40$ and $\leq 18$ with $9.17 \%$ and $0.44 \%$ respectively, were the lowest (Figure 1). As for occupation, students had the highest population of $63.32 \%$,
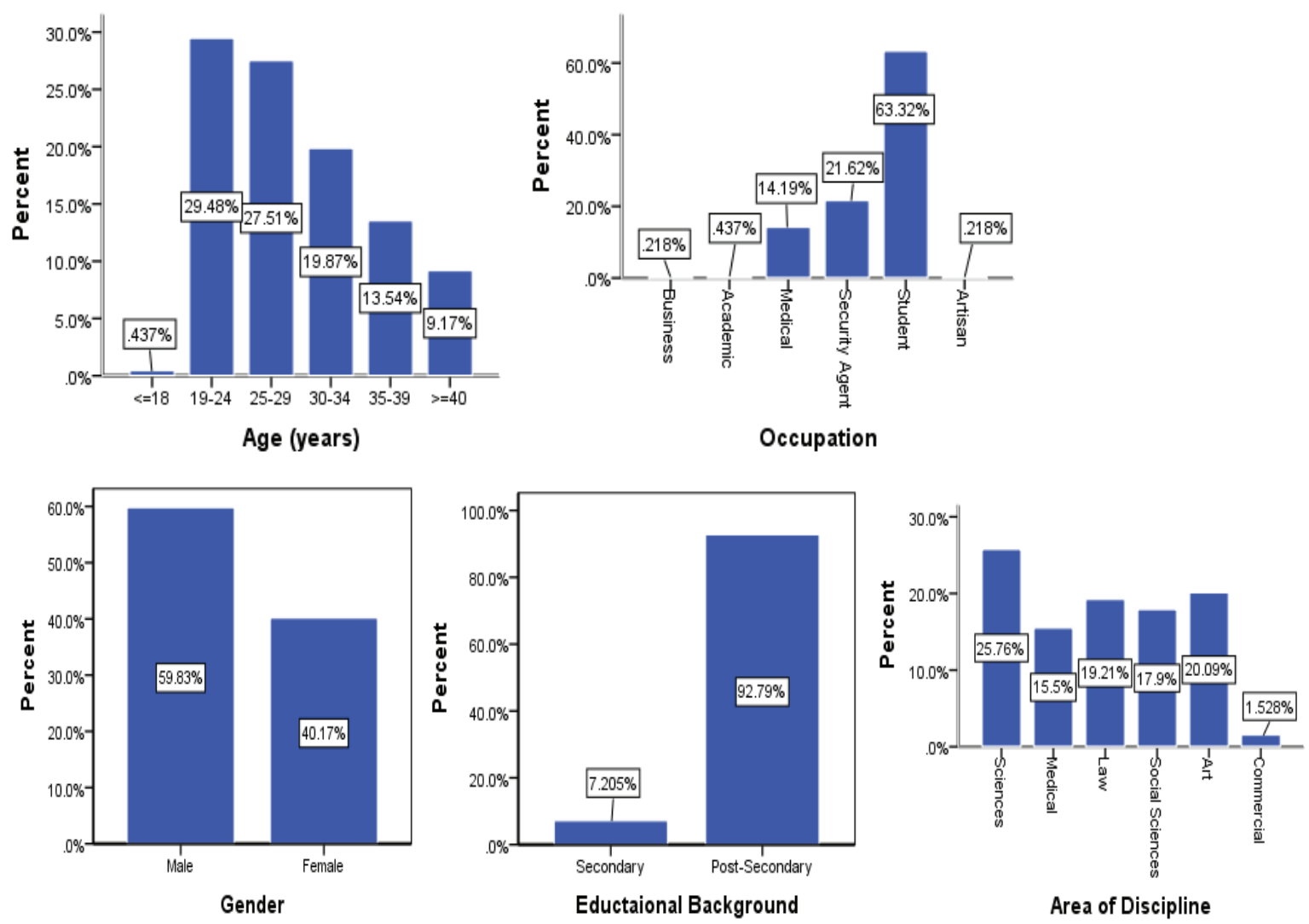

Figure 1: Social demographic distribution of respondents. 
followed by security agents with $21.62 \%$, whereas, business and artisan were the lowest at $0.22 \%$ and $0.22 \%$ respectively. In respect of the area of discipline of the respondent, sciences, art, and law were top of the chart with 25.76, 20.09, and 19.21 $\%$ respectively, and commercial and medical ranked the lowest with $1.53 \%$ and $15.5 \%$ respectively. The educational background of the respondent as demonstrated in figure 1 revealed that the majority of the respondent were postsecondary with $92.79 \%$ and few were secondary with $7.21 \%$.

\section{Level of awareness on national forensic DNA database}

The level of awareness on the prominent role of Forensic DNA database in crime investigation was determined and the result revealed in figure 2. In determining the level of awareness, the following responses were reported: $53.28 \%$ of the total population had no idea about forensic, 19.21\% were uncertain and only $27.54 \%$ knew forensic. The same trend was observed with the knowledge of Forensic DNA profiling: $42.14 \%$ had no knowledge, $22.27 \%$ were uncertain and $35.59 \%$ demonstrated good knowledge of forensic DNA profiling. Likewise, on the knowledge about the National Forensic DNA Database, the trend showed that $48.47 \%$ did not know the National forensic DNA database, $22.27 \%$ were uncertain, and $29.26 \%$ were aware. A total of $4.36 \%$ reported that the National forensic DNA database is useful for storing population records of Nigerians, $36.46 \%$ reported that it is used for storing the DNA profile of all Nigerians, $24.02 \%$ reported it is used for scientific research, and only 35.15\% reported correctly about the key use of National Forensic DNA database which is for criminal identification and comparison of DNA profiles. On the question, 'Does Nigeria holds a National Forensic DNA database', only $24.11 \%$ of respondents got it right with a 'No' response whereas $64.41 \%$ were not sure and $10.48 \%$ responded with a 'yes'. Finally, we observed that $23.58 \%$ got their information on the prominent role of the National Forensic DNA database through the media, 18.56\%
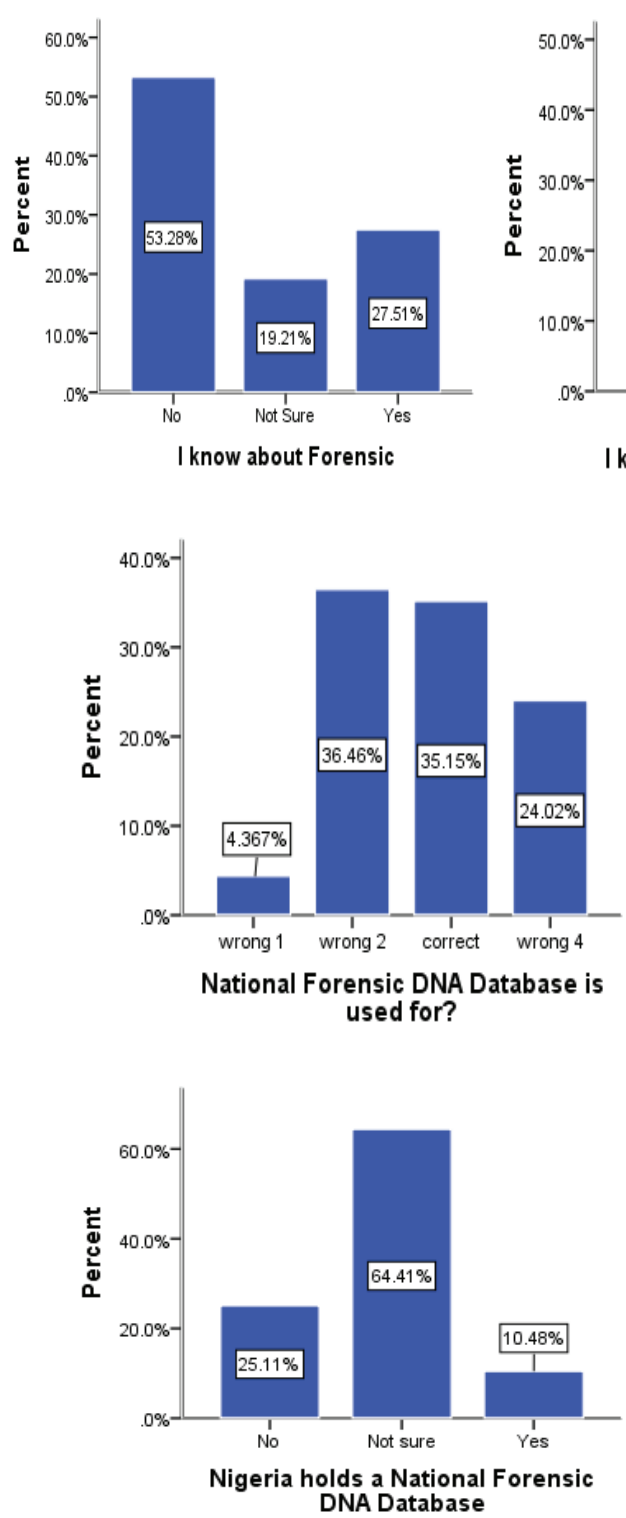

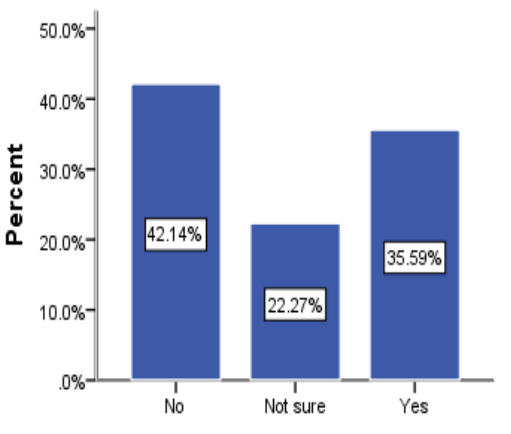

I know about Forensic DNA Profiling

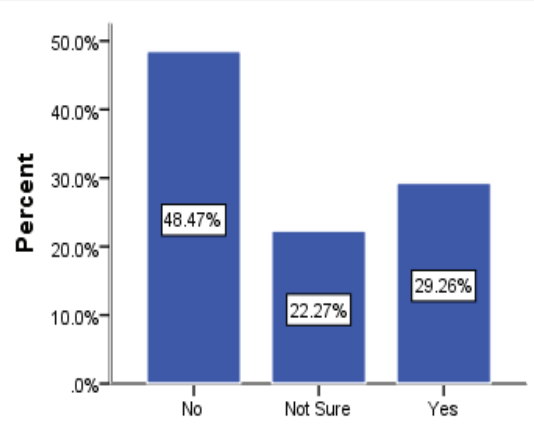

I know about National Forensic DNA Database

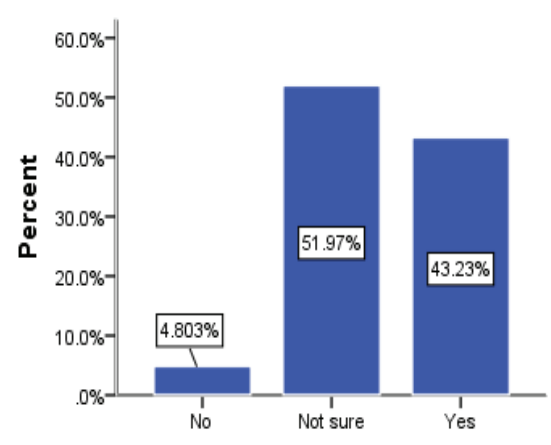

National Forensic DNA Datababse

contribute to crime reduction

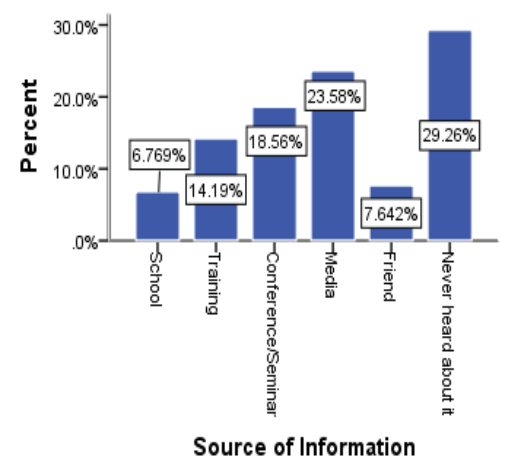

Source of Information 
from conferences/seminars, $14.19 \%$ during training, $6.77 \%$ from school, and the majority of the population have never heard about a National Forensic DNA database neither do they have an awareness on its role in the criminal investigation.

\section{DNA evidence and Nigeria criminal justice system}

The present study further examined the level of awareness of information about DNA evidence and the Nigeria Criminal Justice system. The following questions were measured (Figure 3). There is a relationship between forensic and law; the correct response to this is 'Yes', however, $15.94 \%$ of respondents reported No, $47.82 \%$ were uncertain and only $36.24 \%$ responded correctly with a yes. DNA is admissible as evidence in Nigeria's criminal justice system; the correct response is 'Yes', yet, only $32.31 \%$ responded with a yes, whereas $7.86 \%$ and $59.83 \%$ responded with a No and Not sure respectively. Forensic DNA database is available and in use in Nigeria criminal justice system; the response to this is, 'there is no available forensic DNA database in Nigeria and is not in use in Nigeria criminal justice system', yet, only $20.52 \%$ responded correctly with No, 59.39\% were uncertain, and $20.09 \%$ respondent got it wrong by reporting with a yes. Lastly, if there is existing legislation that allows for the establishment of a National Forensic DNA database in Nigeria; 'No' is the correct response, however, $74.27 \%$ were uncertain, $14.32 \%$ responded with a yes and only $11.41 \%$ responded correctly with a No.

Relationship between the area of discipline and awareness on national forensic DNA database

A non-parametric test (Chi-square) was used to test the hypothesis of an association between the area of discipline and awareness of the National Forensic DNA Database in the present study (Table 1). Additionally, phi and Cramer V was then used to determine the strength of association, and $p<0.05$ was considered significant. Therefore, the statistical analysis revealed that Pearson Chi-square value $=236.594$, $p$-value $=0.00$, and Phivalue $=0.719>0.25$ Very strong. Sincethe $p$ - value of 0.00 is less than the accepted significance level of 0.05 ( $p<0.05$ ), the null hypothesis (Ho) was rejected and the alternative hypothesis (HA) accepted. Hence, the data revealed that area of discipline contributes to the awareness level on forensic DNA database, and as such, law demonstrated the highest level of awareness with 45 count and sciences with 38 count was second to law.
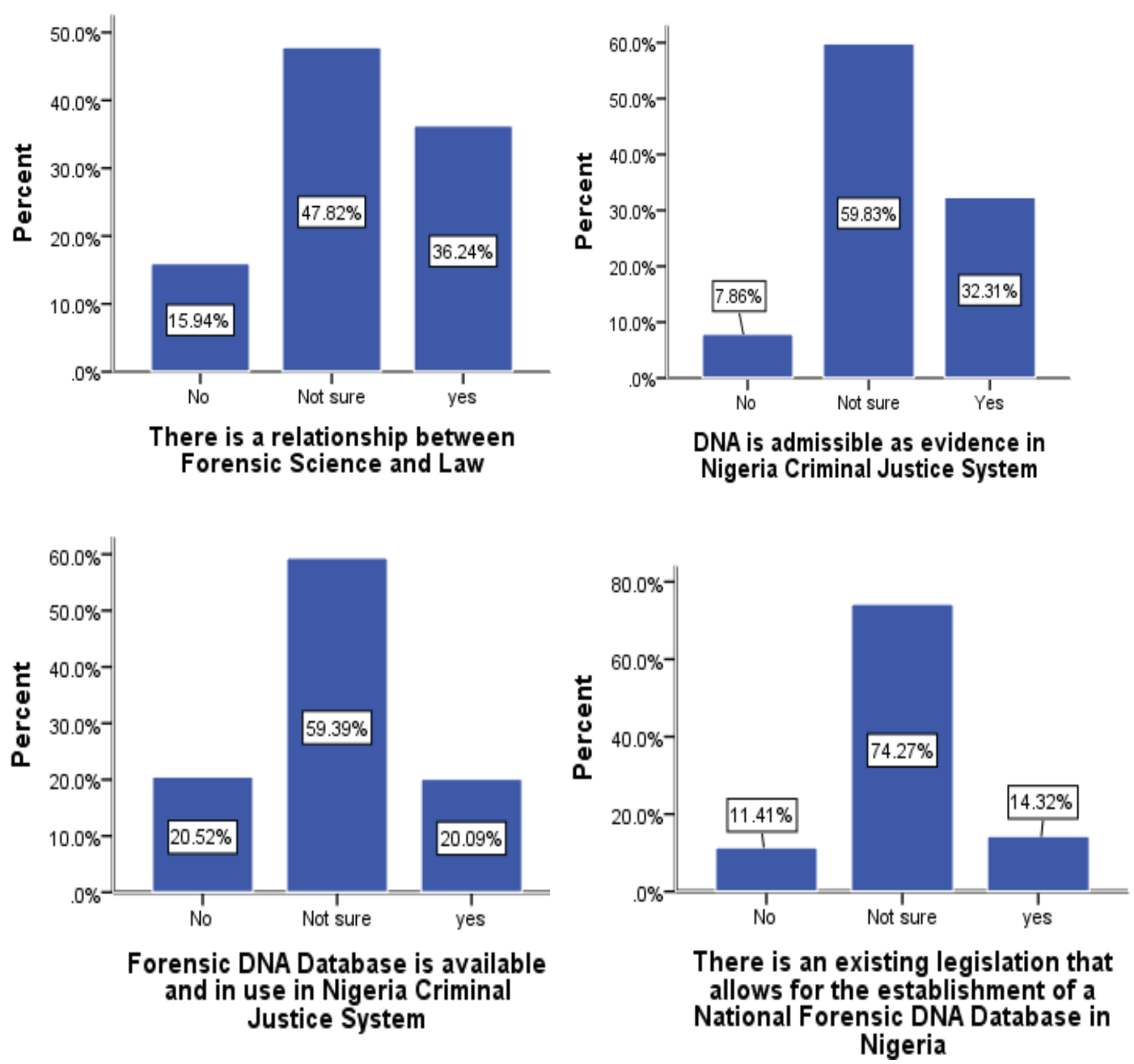

Figure 3: Information about DNA evidence and Nigeria Criminal Justice System. 


\begin{tabular}{|c|c|c|c|c|c|c|c|c|c|c|c|c|}
\hline & \multicolumn{6}{|c|}{ Area of Discipline } & \multirow[b]{2}{*}{ Total $(\mathrm{N})$} & & & & \multirow{2}{*}{\multicolumn{2}{|c|}{$\begin{array}{l}\text { Assumption } \\
\text { (not violated) }\end{array}$}} \\
\hline Responses & Sci & Med & Law & S.S & Art & C & & $\begin{array}{l}\text { Pearson } \\
\text { Chi-Square }\end{array}$ & df & $\begin{array}{l}\text { Assymp.Sig. } \\
\text { (2-sided) }\end{array}$ & & \\
\hline \multicolumn{13}{|c|}{ I know about Forensic } \\
\hline No & 75 & 7 & 39 & 46 & 70 & 7 & 244 & \multirow[b]{4}{*}{236.594} & \multirow[b]{4}{*}{10} & \multirow[b]{4}{*}{.000} & \multirow[b]{4}{*}{.719} & \multirow{4}{*}{$\begin{array}{c}3 \text { cells }(16.7 \%) \text { have expected count less } \\
\text { than } 5 . \text { The minimum expected } \\
\text { count is } 1.34 .\end{array}$} \\
\hline Not Sure & 5 & 56 & 4 & 17 & 6 & 0 & 88 & & & & & \\
\hline Yes & 38 & 8 & 45 & 19 & 16 & 0 & 126 & & & & & \\
\hline Total $(\mathrm{N})$ & 118 & 71 & 88 & 82 & 92 & 7 & 458 & & & & & \\
\hline \multicolumn{13}{|c|}{$\begin{array}{l}\text { I know about National } \\
\text { Forensic DNA Database }\end{array}$} \\
\hline No & 61 & 18 & 33 & 46 & 60 & 4 & 222 & \multirow[b]{4}{*}{38.541} & \multirow[b]{4}{*}{10} & \multirow[b]{4}{*}{.000} & \multirow[b]{4}{*}{.290} & \multirow{4}{*}{$\begin{array}{c}3 \text { cells }(16.7 \%) \text { have expected count less } \\
\text { than } 5 . \text { The minimum expected } \\
\text { count is } 1.56 .\end{array}$} \\
\hline Not Sure & 23 & 17 & 27 & 17 & 16 & 2 & 102 & & & & & \\
\hline Yes & 34 & 36 & 28 & 19 & 16 & 1 & 134 & & & & & \\
\hline Total $(\mathrm{N})$ & 118 & 71 & 88 & 82 & 92 & 7 & 458 & & & & & \\
\hline
\end{tabular}

Additionally, the result (table1) showing the association between an area of discipline and awareness level on the National Forensic DNA Database revealed that Pearson Chi-square value $=38.541, p-$ value $=0.00<0.05$, and Phi value $=0.290>0.25$ Very strong. This means that the $p$ - value $(0.00)$ is less than 0.05 . Since the $p$ - value of 0.00 is less than the accepted significance level of 0.05 (i.e., $p<0.05$ ), the null hypothesis (Ho) was therefore rejected and the alternative hypothesis (HA) accepted. Hence, the data (Table 1) revealed an association between the level of awareness on forensic DNA databases and the area of discipline. In this light, of course, the level of awareness followed this hierarchy; Medicine: 36, Science: 34 , and Law: 34.

\section{Discussion}

Forensic DNA database is an exceptional investigative resource for criminal investigation, and over the years, an extensive body of evidence has demonstrated that forensic DNA database continues to be an indispensable tool in averting miscarriages of justice [2-4,20]. DNA database confers enormous benefits in efficiently and effectively solving crimes, and exonerating the innocent $[4,21]$, and the incredible power of DNA technology as an identification tool brought an incredible change in the criminal justice system [6]. Consequently, many countries around the world now operate forensic DNA-databases to identify owners of crime-related stains [22]. Therefore, the present study provides information as to the level of awareness in Nigeria on the prominent role of the Forensic DNA Database in Criminal Investigation.

Following an extensive search on the level of awareness on the role of forensic DNA database in a criminal investigation around the world, studies in Italy, England, and Portugal revealed a significant level of awareness on the role of forensic DNA database in criminal investigation [2,23,24]. However, our finding as revealed in figure 2, demonstrated a low level of awareness on the role of a forensic DNA database in a criminal investigation in Nigeria. Comparable to other countries in Africa, in South Africa, since the introduction of the Criminal Law (Forensic Procedures) Amendment Act (2013), the use of DNA profiling technology became the gold standard for a criminal investigation [11], and as such, the Forensic DNA Database was developed [12]. Other Africa countries including Egypt, Morocco, Namibia, Botswana, and Sudan have also demonstrated awareness of the important position of forensic in their respective criminal justice system and therefore operate a DNA database. To depict the factual level of awareness on the role of forensic DNA database in a criminal investigation, the present study targeted populations with a high tendency towards information regarding forensic and DNA databases including security agents, lawyers, and university students as revealed in figure 1. Going forward, the result as demonstrated in figure 1, revealed that the distribution pattern of social demographic information visà-vis area of discipline revealed that sciences and law were greater in number; and for occupation, security agents and students dominated. Our finding on the inadequate level of awareness on the prominent role of forensic DNA database in criminal investigation corroborates the report that there is a lack of programs on forensic in Nigeria University and a dearth in professional with forensic expertise [25], and also, a report that there are inadequate forensic science courses in the police training schools [26] and as such privation in the knowledge on the prominent role of forensic DNA database in a criminal investigation. This is reflected in our result (Figure 1), it was observed that $23.58 \%$ got their information on the prominent role of a National Forensic DNA database through the media, $18.56 \%$ from conferences/seminars, $14.19 \%$ during training, $6.77 \%$ from school and the majority of the population have never heard about a National Forensic DNA database neither do they have an awareness on its role in a criminal investigation.

Forensic DNA evidence takes a central position in advancing the administration of justice, and a large body of evidence has revealed that Forensic science and the law epitomizes interdisciplinary epistemologies $[13,27,28]$. As matter of fact, the use of forensic science approach in the criminal justice system is a routine activity, and the use of forensic evidence to aid gamut of activities in the criminal justice system is a recognized phenomenon in the developed countries including England [27], the U.S. [29], and Belgium, [30]. Going forward, the common denominator and distinctiveness existing 
between the countries with a functional DNA database are in the legislative provision. A legislative provision allows for the collection of biological samples for DNA profiling from either the suspect or the victim, or at the scene of a crime in the course of crime investigation, and the storage of the profile generated in the Forensic DNA database [31]. Therefore, the present study further examined the level of awareness on forensic evidence and legislative provisions. The result as demonstrated in figure 3 revealed that there is a privation of knowledge on forensics, DNA evidence, and the legislative provision in Nigeria. As the responses gathered from the questionnaire on "is there a relationship between forensics science and the law", "DNA is admissible as evidence in the Nigerian criminal justice system, and are there existing legislative provision for the establishment of a National Forensic DNA database in Nigeria" validates the privation of knowledge. In practice, the Nigerian court accepts forensic DNA evidence and considers a person empowered to present the evidence either for the defense or prosecuting counsel as an expert witness as provided for in section 67 of the Evidence Act 2011 [32-34].

Additionally, the notable legislative move for the establishment of a forensic DNA database was The Senate Bills: SB: 78 Deoxyribonucleic Acid (DNA) Bill, 2015 sponsored by Senator Theodore A. Orji [35], and also the constitution of the Federal Republic of Nigeria, 1999, made provision for forensic evidence [25].

Finally, a relationship between area of discipline and awareness on the role of Forensic DNA Database in a criminal investigation was determined using a non-parametric test (Chi-square), and the strength of association determined using phi and Cramer V with $p-0.05$ considered significant. The result as demonstrated in table 1 , revealed that area of discipline contributes to the awareness level on forensic DNA database, and as such, law demonstrated the highest level of awareness.

\section{Conclusion}

In conclusion, our results demonstrated that there is an inadequate level of awareness on the prominent role of Forensic DNA database in the criminal investigation. In light of this, it became very necessary to make some recommendations to improve the knowledge and support the establishment of a forensic DNA database for criminal investigation in Nigeria.

\section{Recommendations}

A) It is recommended that the Nigerian government should collaborate with National University Commission to ensure that Nigeria Universities start running programs in forensic science, as this will greatly increase the awareness, and provide the requisite knowledge for expertise in the field of forensic science. Presently, of the over 250 licensed tertiary educational institutions in Nigeria, none of them runs a program in any field related to forensic sciences at the undergraduate level [25].

B) It is recommended that the Nigerian government should also provide adequate funding and equip the laboratory to the International Organization for Standardization (ISO) levels. This will equip the student with hands-on training and also improve the research output in forensic science. Presently, the research contribution in forensic science, particularly forensic DNA profiling is significantly low.

C) The common denominator and peculiarity existing between the countries with functional forensic DNA databases are in their legislation. Although the constitution of the Federal Republic of Nigeria, 1999, made provision for forensic evidence, unfortunately, the executive has not been able to draft any bill with regards to forensic science [25]. Therefore, a need for enactment of the legislation and/or a review of the existing ones regarding the use of DNA as evidence, and the establishment of the DNA database is highly recommended.

\section{References}

1. The Royal Society. Forensic DNA analysis: A primer for courts. 2017 [cited 2020 Oct 18]. Chapter 1: 7. https://royalsociety.org/-/media/ about-us/programmes/science-and-law/royal-society-forensic-dnaanalysis-primer-for-courts.pdf

2. Machado $H$, Silva S. Would you accept having your DNA profile inserted in the National Forensic DNA database? Why? Results of a questionnaire applied in Portugal. Forensic Sci Int Genet. 2014; 8: 132-136. PubMed: https://pubmed.ncbi.nlm.nih.gov/24315600/

3. Hampikian GE, West OA. The genetics of innocence: analysis of 194 U.S. DNA exonerations. Annu Rev Genomics Hum Genet. 2011; 12: 97-120. PubMed: https://pubmed.ncbi.nlm.nih.gov/21721941/

4. Nwawuba SU, Mohammed KA, Adams TB, Omusi PI, Ayevbuomwan DE. Forensic DNA profiling: autosomal short tandem repeat as a prominent marker in crime investigation. Malays J Med Sci. 2020; 27: 22-35. PubMed: https://pubmed.ncbi.nlm.nih.gov/32863743/

5. Govender D. Problems experienced by detectives in the processing and utilisation of crime information at the Rustenburg detective unit, North West Province, South Africa. Acta Criminologica: Southern African J Criminol. 2011; 24: 112-129.

6. Jakovski Z, Renata JA, Aleksandar S, Verica P, Natasa B, et al. The power of forensic DNA data bases in solving crime cases. Forensic Sci Int Genet. 2017; 6 (Suppl): e275-e276.

7. Martins PD, Schmitter H, Schneider PM. A brief history of the formation of DNA databases in forensic science within Europe. Forensic Sci Int. 2001; 119: 225-231.

PubMed: https://pubmed.ncbi.nlm.nih.gov/11376988/

8. Machado $H$, Silva $S$. What influences public views on forensic DNA testing in the criminal field? A scoping review of quantitative evidence. Hum. Genomics. 2019; 13: 1-13.

9. Forensic Genetics Policy Initiative (FDNAPI). Global summary: Botswana. 2016. http://wiki.dnapolicyinitiative.org/index.php?title=Botswana

10. Forensic Genetics Policy Initiative (FDNAPI). Global summary: South Africa. 2018. http://wiki.dnapolicyinitiative.org/index.php?title=South_Africa

11. Heathfield LJ. Policy required for entry of DNA profiles onto the Nationa Forensic DNA Database of South Africa. S Afr J Sci. 2014; 110: 1-3.

12. Wet $\mathrm{S}$, Oosthuizen $\mathrm{H}$, Visser J. DNA profiling and the law in South Africa PER: Potchefstroomse Elektroniese Regsblad. 2011; 14: 171-207. 
13. El-Alfy SH, El-Hafez AF. Paternity testing and forensic DNA typing by multiplex STR analysis using ABI PRISM 310 Genetic Analyzer. J Genet Eng Biotechnol. 2012; 10: 101-112.

14. Tau T, Wally A, Fanie TP. Genetic variation and population structure of Botswana populations as identified with Amp FLSTR Identifiler short tandem repeat (STR) loci. Sci Rep. 2017; 7: 6768.

PubMed: https://pubmed.ncbi.nlm.nih.gov/28754995/

15. Tau T, Davison S, D'Amato ME. Polymorphisms at 17 Y-STR loc in Botswana populations. Forensic Sci Int Genet. 2015; 17: 47-52. PubMed: https://pubmed.ncbi.nlm.nih.gov/25817844/

16. Ngboawaji DN. An Evaluation of the Challenges of Forensic Investigation and Unsolved Murders in Nigeria. AJCJS. 2012; 6: 143-162.

17. McHugh ML. Lessons in biostatistics: The Chi-square test of independence. Biochemia Medica. 2013; 23: 143-149.

18. Rana R, Singhal R. Chi-square test and its application in hypothesis testing. J Pract Cardiovasc Sci. 2015; 1: 69-71.

19. Haldun A. User's guide to correlation coefficients: Review Article. Turk J Emerg Med. 2018; 18: 91-93.

PubMed: https://pubmed.ncbi.nlm.nih.gov/30191186/

20. Johnson P, Williams R. Genetics and Forensics: Making the National DNA Database. Sci Stud. 2003; 16: 22-37.

PubMed: https://www.ncbi.nlm.nih.gov/pmc/articles/PMC1351151/

21. Kirsten D. Universal DNA databases: a way to improve privacy? J Law Biosci. 2017; 4: 637-647.

PubMed: https://pubmed.ncbi.nlm.nih.gov/29868192/

22. Kees VB. Measuring the Effectiveness and Efficiency of Forensic DNA databases. 26 International Symposium on Human Identification. 2016. https://www.promega.com/-/media/files/products-and-services/ genetic-identity/ishi-26-oral- abstracts/9-van-der-beek.pdf

23. Tozzo P, Fassina A, Caenazzo L. Young people's awareness on biobanking and DNA profiling: results of a questionnaire administered to Italian university students. Life Sci Soc Policy. 2017; 13: 9.

PubMed: https://pubmed.ncbi.nlm.nih.gov/28601979/

24. Milot E, Marie MJ, Hugo G, Crispino F. The National DNA Data Bank of Canada: a Quebecer perspective. Front Genet. 2013; 4: 249.

PubMed: https://pubmed.ncbi.nlm.nih.gov/24312124/
25. Alisigwe OJ, Oluwafemi OM. The State of Forensic Science in Crime Investigation and Administration of Justice in Nigeria. Int J Sci \& Eng Res. 2019; 10: 1720-1725.

26. Akhiwu OW, Obaseki D. Knowledge of Nigerian Policemen about Modern Forensics. Ann Biomed Sci. 2014; 13: 1-8.

27. O'Brien E, Daeid NN, Black S. Science in the court: pitfalls, challenges and solutions. Phil Trans R Soc B. 2015; 370: 20150062.

PubMed: https://pubmed.ncbi.nlm.nih.gov/26101291/

28. Robertson J. Understanding how forensic science may contribute to miscarriages of justice. Aust J Forensic Sci. 2013; 45: 109-112.

29. Lynch M. Science, truth, and forensic cultures: The exceptional legal status of DNA evidence. Studies in History and Philosophy of Science Part C: Studies in History and Philosophy of Biological and Biomedical Sciences. 2013; 44: 60-70.

PubMed: https://pubmed.ncbi.nIm.nih.gov/23117027/

30. Vermylen $Y$. The role of the forensic expert in criminal procedures according to Belgian Law. Forensic Sci Int. 2010; 201: 8-13. PubMed: https://pubmed.ncbi.nlm.nih.gov/20471763/

31. Johnson P, Williams R. DNA and Crime Investigation: Scotland and the 'UK National DNA Database'. Scott J Crim Justice Stud. 2004; 10: 71-84. PubMed: https://pubmed.ncbi.nIm.nih.gov/16557290/

32. Kehinde A. Law and Forensic: Techniques of Evidence Gathering and Case Presentation in Court. Nigeria Village Square. 2020. http://www. nigeriavillagesquare.com/articles/law-and-forensic-techniques-ofevidence-gathering-and-case-presentation-in-court.html

33. Amuda-Kannike A. Admissibility of Evidence as It Relates to Electronic Devises, Social Media and Forensic Science. Business Regulations, Law \& Practice: Proshare Nigeria Pvt. Ltd. Ikeja, Lagos, Nigeria. 2018. https://www.proshareng.com/news/Business \%20Regulations, $\% 20$ Law\%20\&\%20Practice/Admissibility-Of-Evidence-As-It-Relates-ToElectronic-Devises--Social-Media-And-Forensic-Science-/39484

34. Evidence Act. Evidence Act. 2020. https://www.global-regulation.com/ law/nigeria/3376439/evidence-act\%252c-2011.html

35. Placbillstract. SB 78: Deoxyribonucleic Acid (DNA) Bill. 2015. http://placbillstrack.org/8th/view.php?getid=1405 